\title{
Pengaruh Gaya Kepemimpinan Terhadap Kinerja Karyawan Pada Pt Sarimelati Kencana Pizza Hut Delivery Cabang Ciputat
}

\author{
Syarifah Ida Farida, Muhammad Makna Fauzi
}

Manajemen, Fakultas Ekonomi, Universitas Pamulang, Jl. Surya Kencana No. 1, Pamulang, 15417

Penulis untuk korespondensi/E-mail: $\underline{\text { dosen01477@unpam.ac.id }}$

\begin{abstract}
Abstrak - Tujuan penelitian adalah untuk mengkaji dan menganalisis : 1) untuk mengetahui gaya kepemimpinan yang ada di PT Sarimelati Kencana Pizza Hut Delivery Cabang Ciputat 2) untuk mengetahui tingkat kinerja karyawan yang ada di PT Sarimelati Kencana Pizza Hut Delivery Cabang Ciputat 2) seberapa besar pengaruh gaya kepemimpinan terhadap kinerja karyawan di PT Sarimelati Kencana Pizza Hut Cabang Ciputat. Penelitian yang dilakukan adalah penelitian kuantitatif dijabarkan dalam analisa deskriptif dan verifikatif dan dilakukan di PT Sarimelati Kencana Pizza Hut Delivery Ciputat dengan jumlah sampel sebanyak 50 orang teknik sampling yang digunakan adalah teknik sampel jenuh. Metode analisis data yang digunakan untuk menguji hipotesis penelitian kuantitatif ini adalah analisis regresi linier sederhana. Hasil penelitian menunjukan bahwa responden : 1) Kondisi gaya kepemimpinan pada indikator yang paling dominan diperoleh dengan skor sebesar 4,28 pada indikator liberal dan kharismatik 2) Kondisi kinerja karyawan pada indikator yang paling dominan diperoleh skor sebesar 4,34 pada indikator disiplin 3) Terdapat adanya pengaruh yang kuat dari gaya kepemimpinan terhadap kinerja karyawan di PT Sarimelati Kencana Pizza Hut Delivery Cabang Ciputat sebesar 0,7821. 4) Terdapat pengaruh yang signifikan dari gaya kepemimpinan terhadap kinerja karyawan sebesar $61,16 \%$.
\end{abstract}

Kata Kunci: Gaya Kepemimpinan dan Kinerja Karyawan

Abstract - The research objective was to study and analyze: 1) To determine the form of leadership style in PT Sarimelati Kencana Pizza Hut Delivery, Ciputat Branch 2) To determine the level of performance of employees at PT Sarimelati Kencana Pizza Hut Delivery Ciputat Branch 2) How big is the influence of style leadership on employee performance at PT Sarimelati Kencana Pizza Hut Ciputat Branch. The research conducted is quantitative research described in descriptive and verification analysis and carried out at PT Sarimelati Kencana Pizza Hut Delivery Ciputat with a total sample of 50 people. The sampling technique used is saturated sampling technique. The data analysis method used to test the hypothesis of this quantitative research is simple linear regression analysis. The results showed that the respondents: 1) The condition of the leadership style on the most dominant indicator was obtained with a score of 4.28 on the liberal and charismatic indicators 2) The condition of the employee's performance on the most dominant indicator obtained a score of 4.34 on the discipline indicator 3) There were there is a strong influence of leadership style on employee performance at PT Sarimelati Kencana Pizza Hut Delivery Ciputat Branch of 0.7821. 4) There is a significant influence of leadership style on employee performance by $61.16 \%$.

Keywords: Leadership Style, Employee Performance 


\section{PENDAHULUAN}

$\mathrm{S}$ umber daya manusia merupakan salah satu faktor penting dalam menunjukan keberhasilan setiap perusahaan, karena hampir seluruh kegiatan operasional perusahaan dijalankan oleh manusia. Oleh karena itu perusahaan harus membentuk sumber daya manusianya untuk dapat terampil dan ahli dibidangnya sehingga tujuan perusahaan dapat tercapai sesuai dengan waktu yang telah ditetapkan. Suatu organisasi juga harus mampu menyusun kebijakan yang tepat untuk mengatasi setiap perubahan yang akan terjadi. Penyusunan kebijakan yang menjadi perhatian manajemen salah satunya menyangkut pemberdayaan sumber daya manusia. Sumber daya manusia yang pontensial apabila didayagunakan secara efektif dan efisien akan bermanfaat untuk menunjang gerak lajunya perusahaan (Koesmono, 2010).

Dalam upaya dapat menunjang keberhasilan tujuan perusahaan tersebut perusahaan harus mampu memberikan rangsangan yang tinggi kepada sumber daya manusia yang dimiliki agar dapat terciptanya keselarasan dalam suatu organisasi, sehingga perusahaan memperhatikan faktor tenaga kerja.

Tabel 1 Hasil Kinerja PT Sarimelati Kencana Pizza Hut Delivery Cabang Ciputat Tahun 20182019

\begin{tabular}{|l|c|c|c|c|c|}
\hline \multicolumn{7}{|c|}{ History } \\
\hline Tanggal & Tipe & $\begin{array}{c}\text { Food } \\
\text { Safety }\end{array}$ & L1 & L2 & L3 \\
\hline $\begin{array}{l}\text { Januari } \\
29,2018\end{array}$ & FSCC & At Standart & 9 & 2 & 0 \\
\hline $\begin{array}{l}\text { April 10, } \\
2018\end{array}$ & ACE & Marginal & 9 & 8 & 0 \\
\hline $\begin{array}{l}\text { Juli 29, } \\
2018\end{array}$ & ACE & At Standart & 5 & 1 & 0 \\
\hline $\begin{array}{l}\text { Desember } \\
20,2018\end{array}$ & FSCC & At Standart & 7 & 3 & 0 \\
\hline $\begin{array}{l}\text { Januari } \\
20,2019\end{array}$ & ACE & Marginal & 9 & 6 & 0 \\
\hline $\begin{array}{l}\text { April 15, } \\
2019\end{array}$ & FSCC & Marginal & 9 & 7 & 0 \\
\hline $\begin{array}{l}\text { Juli 22, } \\
2019\end{array}$ & ACE & $\begin{array}{c}\text { Under- } \\
\text { performance }\end{array}$ & 10 & 6 & 1 \\
\hline
\end{tabular}

Sumber: PT Sarimelati Kencana Pizza Hut Delivery Cabang Ciputat (2019)

Pada tabel 1 diketahui adanya penurunan kinerja pada bulan Juli 2019 dari hasil tersebut menunjukan level $1>10$ level $2>5$ dan level 3 terdapat 1 maka dari standart audit perusahaan menghasilkan underperformance. Hasil itu menunjukan bahwa kinerja karyawan di PT Sarimelati Kencana Pizza Hut Delivery Ciputat mengalami penurunan yang sangat signifikan.

Tabel 2 Hasil Penjualan PT Sarimelati Kencana Pizza Hut Delivery Cabang Ciputat Tahun 20182019

\begin{tabular}{|c|l|l|l|l|}
\hline \multirow{2}{*}{$\begin{array}{c}\text { Tri- } \\
\text { wulan }\end{array}$} & \multicolumn{2}{|c|}{2018} & \multicolumn{2}{c|}{2019} \\
\cline { 2 - 5 } & Target & Realisasi & Target & Realisasi \\
\hline 1 & $\begin{array}{l}\text { Rp300 } \\
\text { juta }\end{array}$ & $\begin{array}{l}\text { Rp303,5 } \\
\text { juta }\end{array}$ & $\begin{array}{l}\text { Rp300 } \\
\text { juta }\end{array}$ & $\begin{array}{l}\text { Rp291,5 } \\
\text { juta }\end{array}$ \\
\hline 2 & $\begin{array}{l}\text { Rp300 } \\
\text { juta }\end{array}$ & $\begin{array}{l}\text { Rp300,5 } \\
\text { juta }\end{array}$ & $\begin{array}{l}\text { Rp300 } \\
\text { juta }\end{array}$ & $\begin{array}{l}\text { Rp290 } \\
\text { juta }\end{array}$ \\
\hline 3 & $\begin{array}{l}\text { Rp300 } \\
\text { juta }\end{array}$ & $\begin{array}{l}\text { Rp298 } \\
\text { juta }\end{array}$ & $\begin{array}{l}\text { Rp300 } \\
\text { juta }\end{array}$ & $\begin{array}{l}\text { Rp287 } \\
\text { juta }\end{array}$ \\
\hline 4 & $\begin{array}{l}\text { Rp300 } \\
\text { juta }\end{array}$ & $\begin{array}{l}\text { Rp290 } \\
\text { juta }\end{array}$ & $\begin{array}{l}\text { Rp300 } \\
\text { juta }\end{array}$ & $\begin{array}{l}\text { Rp285 } \\
\text { juta }\end{array}$ \\
\hline
\end{tabular}

Sumber: PT Sarimelati Kencana Pizza Hut Delivery Ciputat (2019)

Dari tabel hasil penjualan terlihat bahwa adanya penurunan omset penjualan dan hal ini terjadi dikarenakan adanya gaya kepemimpinan yang baru. Dari uraian di atas, mengingat pentingnya gaya kepemimpinan dalam proses kerja suatu perusahaan maka penulis ingin meneliti tentang gaya kepemimpinan di PT Sarimelati Kencana Pizza Hut Delivery Ciputat. Apakah gaya kepemimpinan yang diterapkan di perusahaan ini berpengaruh terhadap kinerja karyawan.

Pengelolaan sumber daya manusia perlu adanya pola gaya kepemimpinan yang tepat sehingga dapat membentuk kesinergian antara atasan dan bawahan. Tuntutan terhadap kebutuhan yang semakin tinggi sebagai dampak krisis ekonomi global sehingga beban kebutuhan hidup pegawai semakin tinggi. Perusahaan harus mampu memperhatikan kebutuhan dan keinginan karyawannya serta memperhatikan tingkat kompensasi yang sesuai bagi karyawan tentunya agar karyawan memiliki loyalitas yang tinggi untuk perusahaan, di samping itu perusahaan harus mendorong karyawan agar dapat bekerja sebaik-baiknya agar tujuan perusahaan dapat tercapai sesuai dengan harapan. Dengan adanya gaya kepemimpinan yang diterapkan oleh pimpinan diharapkan adanya suatu hubungan komunikasi yang harmonis antara pimpinan dan karyawan atau antara karyawan yang satu dengan yang lainnya untuk meningkatkan kinerjanya. 
Gaya kepemimpinan sering kali memusatkan segala keputusan dan kebijakan yang diambil dari dirinya sendiri secara penuh, segala pembagian tugas dan tanggung jawab secara penuh oleh si pemimpin maka disebut juga gaya kepemimpinan otoriter. Seorang pemimpin merupakan contoh, panutan, idola dan pembina bagi seluruh anggota organisasi yang dipimpinnya dalam peningkatan hasil kerja. Wujud dari kepemimpinan antara lain perilaku, sikap, watak serta kebijakan yang dimiliki oleh pimpinan tersebut.

Kepemimpinan dibutuhkan manusia, karena adanya suatu keterbatasan dan kelebihankelebihan tertentu pada manusia. Kepemimpinan ini akan timbul apabila ada orang yang dipengaruhi, orang yang mengakhiri, dan pengarahan akan tercapainya suatu tujuan. Sehingga dapat dikatakan seorang disebut pemimpin apabila orang tersebut dapat mengakhiri orang lain untuk mencapai tujuan meskipun tidak ada ikatan yang formal dengan suatu organisasi.

Demikian halnya dengan Pizza Hut Delivery cabang Tangerang Selatan. Organisasi ini bergerak dibidang kuliner dengan pelayanan pada pesan antar (delivery) dan pesan bawa (take away). Dua jenis pelayanan yang diberikan oleh PHD . Membuat gerai PHD hanya memerlukan tempat untuk membuat produk (kitchen) dan counter hanya melayani pesan bawa dan pesan antar. Dengan adanya gaya kepemimpinan ini diharapkan dengan penerapan berupa adanya hubungan komunikasi yang harmonis antara pemimpin dan bawahan. Penerapan ini terlihat dari proses pengambilan keptusan yang dilakukan dengan mendengarkan suara karyawan yang efektif dan efisien. Pemimpin harus mampu memberikan contoh kepada bawahan, memastikan bahwa para bawahannya termotivasi dan menciptakan kondisi yang menguntungkan untuk melakukan pekerjaan yang lebih giat lagi.

Untuk meningkatkan kinerja karyawan yang baik bukanlah usaha yang mudah karena ada beberapa faktor yang harus di perhatikan, antara lain adalah: lingkungan kerja, suasana kerja, fasilitas perusahaan dan yang paling penting adalah kepemimpinan dan kualitas komunikasi intern yang baik dari atasan ke bawahan. Hal ini dapat dikendalikan melalui tabel data laporan rekapitulasi absensi karyawan yang terjadi setiap tahunnya. Berikut data laporan rekapitulasi absensi karyawan Pizza Hut Delivery Cabang Ciputat.

Tabel 3 Ketidakhadiran Karyawan Tahun 2017-2018 PT Sarimelati Kencana Pizza Hut Delivery Cabang Ciputat

\begin{tabular}{|c|c|c|c|c|}
\hline \multirow{2}{*}{ Tahun } & \multirow{2}{*}{ Jumlah } & \multicolumn{3}{|c|}{ Jumlah Ketidakhadiran } \\
\cline { 3 - 5 } & Karyawan & Alpha & Izin & Sakit \\
\hline 2017 & 50 & 28 & 10 & 11 \\
\hline 2018 & 50 & 30 & 8 & 13 \\
\hline Total & 100 & 58 & 18 & 24 \\
\hline
\end{tabular}

Sumber: Pizza Hut Delivery Cabang Ciputat (2018)

Berdasarkan tabel di atas terlihat tingkat tinggi absensi pegawai Pizza Hut Delivery Ciputat, menunjukan tingkat tinggi sangat rendah dalam ketidakhadiran pegawai dengan total 58 dan akan menimbulkan dampak negatif pada perusahaan sehingga mengakibatkan kegiatan devisi tersebut menjadi terhambat. Dimana semakin besar perputaran yang akan terjadi dalam organisasi maka semakin besar pula kegiatan atau pekerjaan yang menjadi tanggung jawab organisasi perusahaan.

Kepemimpinan dibutuhkan manusia, karena adanya suatu keterbatasan dan kelebihankelebihan tertentu pada manusia. Kepemimpinan ini akan timbul apabila ada orang yang dipengaruhi, orang yang mengakhiri, dan pengarahan akan tercapainya suatu tujuan. Sehingga dapat dikatakan seorang disebut pemimpin apabila orang tersebut dapat mengakhiri orang lain untuk mencapai tujuan meskipun tidak ada ikatan yang formal dengan suatu organisasi.

Peranan pemimpin dalam kehidupan berorganisasi sangat dibutuhkan karena tiada organisasi tanpa pimpinan, jika boleh diibaratkan organisasi itu tubuh tanpa kepala. Dalam kenyataannya seorang pemimpin harus dapat memberikan semangat dan motivasi kepada karyawannya dalam menyelesaikan pekerjaannya. Agar para karyawan termotivasi untuk meningkatkan kualitas kehidupan kerja mereka. Dengan demikian para karyawannya akan berusaha secara terus menerus untuk meningkatkan kinerjanya, sehingga dapat memberikan keuntungan perusahaan. 
Karyawan Pizza Hut Delivery cabang Ciputat dalam menjalankan tugas-tugasnya dituntut untuk mempunyai semangat yang baik sehingga menimbulkan kinerja yang dapat dilaksanakan dengan baik, akurat dan sesuai jadwal yang telah ditetapkan, disini masih banyak masalah yang ada diperusahaan yaitu mengenai kurang harmonisnya hubungan antara pimpinan dengan karyawan, pimpinan tidak membantu bawahan dalam menyelesaikan masalah, perilaku dan sikap yang masih otoriter, pembinaan karyawan yang belum maksimal lingkungsn kerja yang tidak nyaman dan mesin produksi dan fasilitas ruang karyawan sudah banyak kerusakan sehingga mempengaruhi kinerja karyawan yang tidak efektif dan tidak efisien.

PT Sarimelati Kencana Pizza Hut Delivery menyadari bahwa pentingnya gaya kepemimpinan bagi suatu perusahaan dalam rangka meningkatkan kinerja karyawan, sehingga tujuan perusahaan dapat tercapai. Berdasarkan uraian di atas, maka penulis merasa tertarik untuk mengadakan penelitian dengan judul "Pengaruh Gaya Kepemimpinan Terhadap Kinerja Karyawan Pada PT Sarimelati Kencana Pizza Hut Delivery Cabang Ciputat”.

\section{TINJAUAN PUSTAKA}

Gaya kepemimpinan dalam organisasi diarahkan untuk mempengaruhi orang-orang yang dipimpinnya, agar mau berbuat seperti yang diharapkan ataupun diarahkan oleh orang lain yang memimpinnya. (Sutikno, 2014:16). Menurut Thoha (2013:49) bahwa gaya kepemimpinan merupakan norma perilaku yang digunakan oleh seseorang pada saat orang tersebut mencoba mempengaruhi perilaku orang lain yang seperti ia lihat.

Sedangkan Rivai (2014:42) mengatakan gaya kepemimpinan adalah sekumpulan ciri-ciri yang digunakan pimpinan untuk memengaruhi bawahan agar sasaran organisasi tercapai atau dapat pula dikatakan bahwa gaya kepemimpinan adalah pola perilaku dan strategi yang disukai dan sering diterapkan oleh seorang pemimpin. gaya kepemimpinan yang menunjukan, secara langsung maupun tidak langsung, tentang keyakinan seorang pimpinan terhadap kemampuan bawahannya. Artinya gaya kepemimpinan adalah perilaku dan strategi, sebagai hasil kombinasi dari falsafah, keterampilan, sifat, sikap, yang sering diterapkan seorang pemimpin ketika ia mencoba memengaruhi kinerja bawahannya.

Menurut Soekarso dan Agus Sosro (2010:44) terdapat berbagai gaya kepemimpinan yaitu:

1. Gaya Kepemimpinan Otoriter/Authoritarian Kepemimpinan Otoriter adalah gaya pemimpin yang memusatkan segala keputusan dan kebijakan yang diambil dari dirinya sendiri secara penuh. Segala pembagian tugas dan tanggung jawab dipegang oleh si pemimpin yang otoriter tersebut, sedangkan para bawahan hanya melaksanakan tugas yang telah diberikan.

2. Gaya

Demokratis/Democratic

Kepemimpinan

Gaya kepemimpinan demokratis adalah gaya yang memberikan wewenang secara luas kepada para bawahan. Setiap ada permasalahan selalu mengikutsertakan bawahan sebagai suatu sistem yang utuh. Dalam gaya kepemimpinan demokratis pemimpin memberikan banyak informasi tentang tugas serta tanggung jawab para bawahannya.

3. Gaya Kepemimpinan Bebas/Liberal

Gaya kepemimpinan bebas ini pemimpinan terlibat dalam kuantitas yang kecil dimana para bawahannya yang secara aktif menentukan tujuan dan penyelesaian masalah yang dihadapi.

4. Gaya Kepemimpinan Populis

Gaya kepemimpinan Populis ini adalah tipe pemimpin yang mampu membangun rasa solidaritas pada pimpinan dan bawahan serta para pengikutnya.

5. Gaya Kepemimpinan Kharismatik

Seorang pemimpin yang kharismatik memiliki karakteristik khusus yaitu daya tariknya yang sangat memikat, sehingga mampu memperoleh pengikut yang sangat besar dan para pengikutnya tidak selalu dapat menjelaskan secara konkrit mengapa orang tersebut itu dikagumi. Hingga sekarang, para ahli belum berhasil menemukan sebab-sebab mengapa seorang pemimpin memiliki kharisma. Yang diketahui ialah bahwa pemimpin yang demikian memiliki daya penarik yang amat besar.

6. Gaya Kepemimpinan Kooperatif Dimaksudkan sebagai gaya kepemimpinan ciri khas Indonesia, yaitu gaya kepemimpinan yang mempunyai jiwa Pancasila, yang memiliki wibawa dan daya 
untuk membawa serta memimpin masyarakat lingkungannya kedalam kesadaran kehidupan kemasyarakatan dan kenegaraan.

Kinerja merupakan suatu yang dinilai dari apa yang dilakukan oleh seorang karyawan. Dalam kerjanya dengan kata lain, kinerja individu adalah bagaimana seorang karyawan yang meningkat akan turut mempengaruhi atau meningkatkan prestasi organisasi sehingga tujuan organisasi sehingga tujuan organisasi yang telah ditentukan dapat dicapai.

Menurut Hasibuan (2012:94) definisi kinerja karyawan adalah suatu hasil yang dicapai oleh seseorang dalam melaksanakan tugas-tugas yang dibebankan kepadanya. Menurut Vethzal Rifai Ahmad Fauzi dan Wibowo Phil (2016) kinerja adalah hasil atau tingkat keberhasilan seseorang secara keseluruhan selama periode tertentu didalam melaksanakan tugas dibandingkan dengan berbagai kemungkinan, seperti standar hasil kerja, target atau sasaran atau kriteria yang telah ditentukan terlebih dahulu dan telah disepakati bersama.

Kinerja merupakan suatu fungsi dari motivasi dan kemampuan. Untuk menyelasikan tugas atau pekerjaan, seseorang hasrus memiliki derajat kesediaan dan tingkat kemapuan tertentu (Hersey and Blan Hard dalam Manguprawira, 2015). Kesediaan dan keterampilan seseorang tidaklah cukup efektif untuk mengerjakan sesuatu tanpa pemahaman yang jelas tentang apa yang akan dikerjakan dan bagaimana mengerjakannya. Menurut Sedarmayanti (2013) menyatakan bahwa kinerja merupakan sistem yang digunakan untuk menilai dan mengetahui apakah seeorang karywan telah melaksnakan pekerjaanya secara keseluruhan, atau merupakan perpaduaan dari hasil kerja (apa yang harus dicapai seseorang). Selanjutnya Mangkunegara (2014) menyatakan bahwa kinerja sumber daya manusia merupakan istilah dari kata job performance atau actual performance (prestasi kerja) adalah hasil kerja secara kualitas dan kuantitas yang dicapai oleh seseorang karyawan/pegawai dalam melaksankan tugasnya sesuai dengan tanggung jawab yang diberikan kepadanya.

Kinerja (performance appraisal) adalah proses melalui mana organisasi-organisasi mengevaluasi atau menilai prestasi kerja karyawan dimana dalam kegiatan ini dapat memperbaiki keputusan-keputusan personalia dan memberikan umpan balik kepada karyawan tentang pelaksanaan kerja mereka (Handoko, 2016). Sedangkan menurut Simanjuntak (2013) kinerja adalah tingkat pencapaian hasil atas pelaksanaan tugas tertentu dalam hal inimencakup kinerja individu, kinerja kelompok, kinerja perusahaan yang dipengaruhi faktor intern dan ekstern.

Indikator kinerja karyawan yaitu (Hasibuan, 2012: 94):

a. Tanggung Jawab

Tanggung jawab merupakan suatu kewajiban karyawan dalam mempertanggung jawabkan kebijakannya, pekerjaannya, hasil kerjanya, sarana dan prasarana yang digunakan serta perilaku karyawan dalam bekerja.

b. Tenggang Rasa

Tenggang rasa merupakan bentuk sikap pimpinan yang dilakukan olehkaryawan atas hubungannya disuatu organisasi. Peranan inilah menjadi pimpinan lebih menghargai antar sesama karyawan dengan perwujudan tingkah laku, ucapan dan tindakan.

c. Kerjasama

Kerjasama adalah kesediaan karyawan berprestasi dan bekerja sama dengan karyawan lainnyasecara vertikal dan horizontal didalam maupun diluar pekerjaannya.

d. Disiplin

Mencerminkan kepatuhan karyawan dalam mematuhi peraturan-peraturan yang ada dan melakukan pekerjaannya sesuai dengan instruksi yang diberikan kepadanya.

e. Kejujuran

Kejujuran adalah sikap (attitude) karyawan untuk bekerja secara baik dan benar tanpa ada tindakan manipulasi atau berkata yang sebenarnya tanpa mengurangi sedikitpun apa saja yang akan kita sampaikan kepada orang lain. Sehingga tindakan dari karyawan sesuai dengan peraturan yang ditentukan perusahaan.

f. Loyalitas

Loyalitas adalah suatu bentuk kesetiaan dan pengabdian karyawan untuk perusahaan tempat mereka bekerja. Serta sikap kesediaan karyawan dalam menjaga kemauan dan hasrat bekerjanya sebagai bentuk loyalitas pada perusahaan. 


\section{METODE PENELITIAN}

Metode penelitian ini digunakan pada penelitian ini adalah metode kuantitatif. Menurut Sugiyono (2015:7), metode kuantitatif dinamakan metode tradisional, karena metode ini sudah cukup lama digunakan sehingga sudah mentradisi sebagai metode untuk penelitian. Dinamakan metode kuantitatif karena data dalam penelitian ini menggunakan angka-angka dan analisis menggunakan statistik.

Populasi yang digunakan karyawan bagian delivery dan kitchen PT Sari Melati Kencana Pizza Hut Delivery Cabang Ciputat adalah 50 orang. Sampel yang digunakan teknik Sampling jenuh adalah teknik penentuan sampel bila semua anggota populasi digunakan sebagai sampel yaitu sebanyak 50 sampel.

a. Analisis Koefisien Korelasi Pearson (R)

Korelasi menurut Sugiyono (2015: 183), adalah angka yang menunjukkan arah dan kuatnya hubungan antara dua variabel atau lebih. Arah dinyatakan dalam bentuk hubungan positif atau negatif, sedangkan kuatnya hubungan dinyatakan dalam besarnya koefisien korelasi. Analisis korelasi berguna untuk menentukan suatu besaran yang menyatakan bagaimana kuat hubungan suatu variabel dengan variabel lain.

b. Analisis Regresi Linier Sederhana

Penelitian ini menggunakan 2 variabel yaitu variabel $\mathrm{X}$ dan variabel $\mathrm{Y}$. Oleh karena itu, untuk mengetahui apakah ada hubungan yang kuat atau lemah menggunakan analisis regresi linier sederhana.

Persamaan umum regresi linier sederhana dalam penelitian ini dinyatakan dengan rumus sebagai berikut:

$$
\mathrm{Y}=\mathrm{a}+\mathrm{bX}
$$

c. Analisis Koefisien Determinasi (KD)

Berdasarkan dari pengertian di atas, maka koefisien determinasi merupakan analisis untuk mengetahui seberapa besar (persen) kontribusi variabel bebas terhadap variabel terikatnya. Adapun besarnya kontribusi dari $\mathrm{X}$ terhadap nilai $\mathrm{Y}$ dapat dihitung dengan rumus sebagai berikut:

$$
\mathrm{Kd}=\mathrm{r}^{2} \mathrm{X} 100 \%
$$

Keterangan:

$$
\begin{array}{ll}
\mathrm{Kd} & =\text { Koefisien determinasi } \\
\mathrm{r} & =\text { Koefisien korelasi }
\end{array}
$$

d. Pengujian Hipotesis (Uji t)

Kriteria penolakan dan penerimaan hipotesis $\mathrm{H}_{0}$ adalah:

1) Jika $t_{\text {hitung }}>t_{\text {tabel }}$, maka $\mathrm{H}_{0}$ ditolak dan $\mathrm{H}_{1}$ diterima.

2) Jika $t_{\text {hitung }}<t_{\text {tabel }}$, maka $\mathrm{H}_{0}$ diterima dan $\mathrm{H}_{1}$ ditolak.

\section{HASIL DAN PEMBAHASAN}

Penelitian ini menggunakan metode kuantitatif dengan responden sebanyak 50 orang di bagian lini terbawah yaitu bagian kitchen dan delivery dengan menggunakan teknik sampling jenuh. Adapun struktur Organisasi yang ada di Pizza Hut Delivery sebagai berikut :

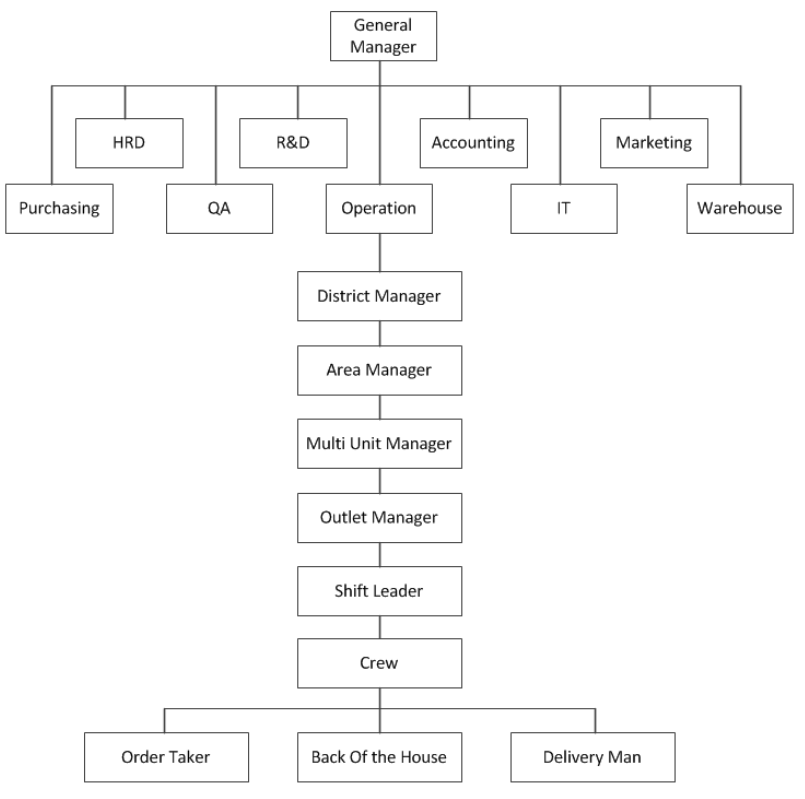

\section{Gambar 1. Struktur Organisasi}

Sumber: PT Sarimelati Kencana Pizza Hut Delivery Cabang Ciputat (2018)

Berdasarkan jenis kelaminnya, maka responden dalam penelitian ini dapat dilihat pada tabel 4 .

Tabel 4. Jenis Kelamin

\begin{tabular}{|c|l|l|l|}
\hline No & $\begin{array}{c}\text { Jenis } \\
\text { Kelamin }\end{array}$ & Jumlah & $\begin{array}{c}\text { Presentase } \\
(\mathbf{\%})\end{array}$ \\
\hline 1 & Laki-laki & 37 & $74 \%$ \\
\hline 2 & Perempuan & 13 & $26 \%$ \\
\hline & Jumlah & 50 & $100 \%$ \\
\hline
\end{tabular}

Sumber : Data olahan kuesioner (2018)

Tabel 4. jenis kelamin menunjukan dari 50 responden yang jumlah frekuensi responden laki-laki paling banyak dalam penelitian ini adalah 37 orang (74\%) dan responden 
perempuan adalah sebanyak 13 orang (26\%). Berdasarkan hasil tabulasi menurut usia, maka responden dalam penelitian ini dapat di klasifikasikan seperti pada tabel 5 .

Tabel 5. Usia Responden

\begin{tabular}{|c|c|c|c|}
\hline No & $\begin{array}{c}\text { Kelompok } \\
\text { Usia }\end{array}$ & Jumlah & $\begin{array}{c}\text { Presentase } \\
(\%)\end{array}$ \\
\hline 1 & $21-25$ & 24 & $46 \%$ \\
\hline 2 & $26-35$ & 21 & $38 \%$ \\
\hline 3 & $36-45$ & 5 & $16 \%$ \\
\hline \multicolumn{2}{|c|}{ Jumlah } & 50 & $100 \%$ \\
\hline
\end{tabular}

Sumber : Data olahan kuesioner (2018)

Pada tabel 5 menunjukan bahwa usia responden paling banyak dalam penelitian ini adalah responden yang berusia 21-25 tahun yaitu sebanyak 24 orang (46\%), responden yang berusia antar 26-35 tahun yaitu sebanyak 21 orang $(38 \%)$ dan responden yang berusia antara 36-45 tahun yaitu sebanyak 5 orang (16\%). Pendidikan yang ditempuh, maka responden dalam penelitian ini dapat diklasifikasikan seperti pada tabel 6 .

Tabel 6. Pendidikan Responden

\begin{tabular}{|c|l|l|l|}
\hline No & $\begin{array}{c}\text { Tingkat } \\
\text { Peendidikan }\end{array}$ & Jumlah & $\begin{array}{c}\text { Presentase } \\
(\mathbf{\%})\end{array}$ \\
\hline 1 & SMA/SMK & 30 & $56 \%$ \\
\hline 2 & Diploma & 8 & $12 \%$ \\
\hline 3 & Strata 1 & 12 & $32 \%$ \\
\hline & Jumlah & 50 & $100 \%$ \\
\hline
\end{tabular}

Sumber : Data Olahan Kuesioner (2018)

Pada tabel 6. Pendidikan menunjukan bahwa dari 50 responden yang jumlah frekuensi responden yang tingkat pendidikan paling tinggi adalah S1 yaitu sebanyak 12 orang (32\%), responden yang tingkat pendidikannya Diploma adalah sebanyak 8 orang (12\%), selanjutnya responden yang tingkat pendidikannya SMA/SMK adalah 30 orang (56\%).

Kalkulasi hitungan lamanya karyawan yang bekerja pada PT Sarimelati Kencana Pizza Hut Delivery Ciputat, maka responden dalam penelitian ini dapat diklasifikasikan seperti pada tabel 7.

Tabel 7. Lama Bekerja

\begin{tabular}{|c|l|l|l|}
\hline No & $\begin{array}{l}\text { Jenis } \\
\text { Kelamin }\end{array}$ & Jumlah & $\begin{array}{l}\text { Presentase } \\
(\%)\end{array}$ \\
\hline 1 & $\leq 1$ Tahun & 10 & $18 \%$ \\
\hline 2 & $1-3$ Tahun & 20 & $40 \%$ \\
\hline 3 & $3-6$ Tahun & 15 & $26 \%$ \\
\hline 2 & $\geq 6$ Tahun & 5 & $16 \%$ \\
\hline
\end{tabular}

\begin{tabular}{|l|l|l|l|}
\hline No & $\begin{array}{l}\text { Jenis } \\
\text { Kelamin }\end{array}$ & Jumlah & $\begin{array}{l}\text { Presentase } \\
(\boldsymbol{\%})\end{array}$ \\
\hline Jumlah & & 50 & $100 \%$ \\
\hline
\end{tabular}

Sumber : Data olahan kuesioner (2018)

Dari tabel 7 dijelaskan bahwa untuk karakteristik responden berdasarkan lamanya menjadi karyawan $\leq 1$ tahun sebanyak 10 responden dari total 50 responden atau sekitar 19 $\%$. Untuk $1-3$ tahun sebanyak 20 responden dari total 50 responden atau sekitar $40 \%$. Untuk 3 -6 tahun sebanyak 17 responden dari total 50 responden atau sekitar $20 \%$, dan untuk $\geq 6$ tahun sebanyak 10 responden dari total 50 responden atau sekitar $20 \%$ dari total keseluruhan responden.

\section{Tabel 8. Uji Validitas Gaya Kepemimpinan}

(X)

\begin{tabular}{|c|c|c|c|c|}
\hline No & Pernyataan & $\begin{array}{l}\text { Koefisien } \\
\text { Korelasi } \\
(\text { t- } \\
\text { hitung })\end{array}$ & $\begin{array}{c}\text { Distribusi } \\
\text { t-tabel }\end{array}$ & Keputusan \\
\hline 1 & $\begin{array}{l}\text { Pemimpin mengambil } \\
\text { Keputusan yang } \\
\text { menanyakan pendapat } \\
\text { bawahanya }\end{array}$ & 0,659 & 0,279 & Valid \\
\hline 2 & $\begin{array}{l}\text { Setiap keputusan yang } \\
\text { diambil pimpinan } \\
\text { selalu } \\
\text { mempertimbangkan } \\
\text { masukan karyawan } \\
\end{array}$ & 0,653 & 0,279 & Valid \\
\hline 3 & $\begin{array}{l}\text { Pimpinan menyerahkan } \\
\text { keputusan dan } \\
\text { pekerjaan kepada } \\
\text { karyawan }\end{array}$ & 0,682 & 0,279 & Valid \\
\hline 4 & $\begin{array}{l}\text { Pimpinan menunjukan } \\
\text { empati kepada } \\
\text { karyawannya }\end{array}$ & 0,657 & 0,279 & Valid \\
\hline 5 & $\begin{array}{l}\text { Pimpinan selalu } \\
\text { mengutamakan kerja } \\
\text { tim }\end{array}$ & 0,624 & 0,279 & Valid \\
\hline 6 & $\begin{array}{l}\text { Pemimpin tidak segan } \\
\text { mengucapkan terima } \\
\text { kasih dan salam kepada } \\
\text { karyawannya }\end{array}$ & 0,647 & 0,279 & Valid \\
\hline 7 & $\begin{array}{l}\text { Pimpinan tidak ragu } \\
\text { mengucapkan selamat } \\
\text { atas keberhasilan } \\
\text { bawahanya }\end{array}$ & 0,548 & 0,279 & Valid \\
\hline 8 & $\begin{array}{l}\text { Komunikasi antara } \\
\text { pimpinan dan } \\
\text { bawahannya terjalin } \\
\text { dengan baik }\end{array}$ & 0,637 & 0,279 & Valid \\
\hline 9 & $\begin{array}{l}\text { Adanya hubungan dan } \\
\text { arahan yang membantu } \\
\text { kelancaran pekerjaan } \\
\text { karyawannya }\end{array}$ & 0,639 & 0,279 & Valid \\
\hline 10 & $\begin{array}{l}\text { Pimpinan memberikan } \\
\text { kesempatan kepada } \\
\text { karyawan untuk } \\
\text { memberikan pendapat } \\
\text { dan masukan }\end{array}$ & 0,462 & 0,279 & Valid \\
\hline
\end{tabular}


Untuk mengetahui kuesioner yang disebarkan sudah valid atau belum maka peneliti menyebarkan ke beberapa responden dan diketahui bahwa variabel $X$ yaitu gaya kepemimpinan semua indikator pernyataanya valid. Hal ini dapat diketahui dari perhitungan menggunakan rumus korelasi product moment, maka $\mathrm{r}_{\text {-hitung }}(0,659)>\mathrm{r}-70$ able $(0,279)$, berarti butir pernyataan no.1 dinyatakan valid dan seperti itu cara perhitungan pengujian validitas untuk pernyataan no 2 sampai no 10 . $>t_{\text {tabel }}$. Dapat disimpulkan bahwa ke-10 butir pernyataan tersebut dinyatakan Valid. Untuk itu kuesioner yang digunakan layak untuk diolah sebagai data penelitian.

Begitupula dengan variabel $\mathrm{Y}$ yaitu Kinerja, peneliti menyebarkan kuesioner ke beberapa responden dan hasilnya dinyatakan semua indikator pernyataan valid dengan menggunakan rumus korelas product moment.

Tabel 9. Uji Validitas Kinerja Karyawan (Y)

\begin{tabular}{|c|c|c|c|c|}
\hline No & Pernyataan & $\begin{array}{l}\text { Cronbac } \\
\text { th Alpha }\end{array}$ & $\begin{array}{l}\text { Standart } \\
\text { Cronbat } \\
\text { h Alpha }\end{array}$ & $\begin{array}{c}\text { Keput } \\
\text { usan }\end{array}$ \\
\hline 1 & $\begin{array}{l}\text { Dalam melaukan } \\
\text { pekerjaan, karyawan } \\
\text { selalu mengerjakan } \\
\text { dengan penuh } \\
\text { perhitungan }\end{array}$ & 0,300 & 0,279 & Valid \\
\hline 2 & $\begin{array}{l}\text { Perhatian perusahaan } \\
\text { terhadap kualitas kerja } \\
\text { karyawan semakin } \\
\text { meningkat }\end{array}$ & 0,835 & 0,279 & Valid \\
\hline 3 & $\begin{array}{l}\text { Alasan bersikap tegas } \\
\text { kepada karyawan, } \\
\text { ketika karyawan } \\
\text { melakukan kesalahan }\end{array}$ & 0,779 & 0,279 & Valid \\
\hline 4 & $\begin{array}{l}\text { Tingkat pencapaian } \\
\text { volume kerja yang } \\
\text { dihasilkan karyawan } \\
\text { telah sesuai dengan } \\
\text { harapan perusahaan }\end{array}$ & 0,696 & 0,279 & Valid \\
\hline 5 & $\begin{array}{l}\text { Perusahaan } \\
\text { menetapkan target } \\
\text { dengan penuh } \\
\text { perhitunga }\end{array}$ & 0,636 & 0,279 & Valid \\
\hline 6 & $\begin{array}{l}\text { Karyawan taat } \\
\text { terhadap semua aturan } \\
\text { dan prosedur kerja } \\
\text { yang ditetapkan dalam } \\
\text { suatu pekerjaan }\end{array}$ & 0,499 & 0,279 & Valid \\
\hline 7 & $\begin{array}{l}\text { Setiap karyawan dapat } \\
\text { dengan baik } \\
\text { berkerjasama antar } \\
\text { rekan kerja }\end{array}$ & 0,612 & 0,279 & Valid \\
\hline 8 & $\begin{array}{l}\text { Inisiatif karyawan } \\
\text { dalam menerima hasil } \\
\text { keputusan manajemen } \\
\text { sudah bersifat } \\
\text { mendukung }\end{array}$ & 0,459 & 0,279 & Valid \\
\hline 9 & $\begin{array}{l}\text { Selalu bersikap jujur } \\
\text { dalam melaksanakan } \\
\text { pekerjaan }\end{array}$ & 0,578 & 0,279 & Valid \\
\hline
\end{tabular}

\begin{tabular}{|c|l|c|c|c|}
\hline No & Pernyataan & $\begin{array}{c}\text { Cronbac } \\
\text { th Alpha }\end{array}$ & $\begin{array}{c}\text { Standart } \\
\text { Cronbat } \\
\text { h Alpha }\end{array}$ & $\begin{array}{c}\text { Keput } \\
\text { usan }\end{array}$ \\
\hline 10 & $\begin{array}{l}\text { Menjaga rahasia } \\
\text { perusahaan dari pihak } \\
\text { - pihak yang tidak } \\
\text { berkepentingan }\end{array}$ & 0,552 & 0,279 & Valid \\
\hline
\end{tabular}

Sumber: Data diolah oleh peneliti (2019)

Dari hasil pengolahan data diketahui variabel Y indikator pernyataannya valid semua yang dapat diketahui melalui $r_{\text {hitung }}(0,300)>r_{\text {tabel }}(0,279)$, berarti butir pernyataan no.1 dinyatakan valid dan seperti itu cara perhitungan pengujian validitas untuk pernyataan no 2 sampai no 10. Dapat disimpulkan bahwa ke10 butir pernyataan tersebut dinyatakan Valid. Untuk itu kuesioner yang digunakan layak untuk diolah sebagai data penelitian.

Setelah mengetahui semua variabel valid, maka selanjutya mencari reliabel dari semua indikator di masing-masing variabel. Hal ini dilakukan untuk mengetahui alat ukur yang digunakan dapat dipercaya atau tidak dan dapat digunakan oleh peneliti lainnya dalam melakukan penelitian dengan responden yang berbeda, tetapi dengan pernyataan dan indikator yang sama. Dari hasil uji reliabel dapat diketahui Variabel $\mathrm{X} \mathrm{rc} \alpha>\mathrm{r}_{\text {tabel }}$ atau dengan ketentuan $\mathrm{a}=$ $5 \%$ maka besar $r_{\text {tabel }}=0,279$ maka varians butir item variabel x $(0,809>0,279)$ dapat dikatakan Reliabel. Untuk itu kuesioner yang digunakan layak untuk diolah sebagai data penelitian. Uji reliabel Variabel $Y$ rc $\alpha>r_{\text {tabel }}$ atau dengan ketentuan $\mathrm{a}=5 \%$ maka besar $\mathrm{r}_{\text {tabel }}=0,279$ maka varians butir item variabel y $(0,790>0,279)$ dapat dikatakan Reliabel. Untuk itu kuesioner yang digunakan layak untuk diolah sebagai data penelitian.

Langkah selanjutnya adalah mencari nilai ratarata dari setiap jawaban responden dimana hasilnya diinterpretasikan berpedoman pada tabel di bawah ini.

Tabel 10. Kriteria Tanggapan Responden

\begin{tabular}{|c|l|}
\hline $\begin{array}{c}\text { Kriteria } \\
\text { Nilai }\end{array}$ & \multicolumn{1}{c|}{ Keputusan } \\
\hline $1,00-1,79$ & Sangat Tidak Setuju / Sangat Tidak Baik \\
\hline $1,80-2,59$ & Tidak Setuju / Tidak Baik \\
\hline $2,60-3,39$ & Kurang Setuju / Kurang Baik \\
\hline $3,40-4,19$ & Setuju / Baik \\
\hline $4,20-5,00$ & Sangat Setuju / Sangat Baik \\
\hline \multicolumn{2}{|c|}{ Sumber: Sugiyono (2016:96) }
\end{tabular}

Berdasarkan hasil olah data dari hasil kuesioner yang diisi oleh 50 orang responden dapat 
diketahui bahwa tanggapan responden atas pertanyaan pada variabel Gaya kepemimpinan (X) memberikan jawaban yang beragam. Secara keseluruhan tanggapan responden atas pernyataan pada variabel Gaya Kepemimpinan dengan nilai indikator yang tertinggi adalah Khasrismatik dan Liberal diperoleh skor sebesar 4,28 dan nilai indikator yang terendah adalah Otoriter diperoleh skor sebesar 4,06. Dan diperoleh rata-rata skor sebesar 4.12 termasuk pada rentang skala 3,40 - 4,19 dengan kriteria baik. Responden yang memberikan penilaian sangat setuju dan setuju sebesar $90 \%$ dan responden yang menjawab kurang setuju, tidak setuju dan sangat tidak setuju sebesar $10 \%$.

Tanggapan responden atas pertanyaan pada variabel Kinerja Karyawan (Y) memberikan jawaban yang beragam. Secara keseluruhan tanggapan responden atas pernyataan pada variabel Kinerja Karyawan dengan nilai indikator yang tertinggi adalah Disiplin diperoleh skor sebesar 4,34 dan nilai indikator yang terendah adalah Tenggang Rasa diperoleh skor sebesar 4,11. Dan diperoleh rata-rata skor sebesar 4.23 termasuk pada rentang skala 4,20 5,00 dengan kriteria sangat baik. Responden yang memberikan penilaian sangat setuju dan setuju sebesar $87,60 \%$ dan responden yang menjawab kurang setuju, tidak setuju dan sangat tidak setuju sebesar $12,40 \%$.

Dalam metode kuantitatif untuk mengetahui seberapa besar pengaruh suatu variabel maka harus mencari tahu seberapa kuat atau lemahnya hubungan antara variabel $\mathrm{X}$ dan variabel $\mathrm{Y}$. Oleh karena itu, peneliti menggunakan regresi linier sederhana dan diketahui bahwa koefisien korelasi gaya kepemimpinan terhadap kinerja karyawan mempunyai hubungan yang kuat karena masuk dalam kategori $\mathbf{r x y}=\mathbf{0 , 7 8 2 1}$. Dengan demikian pula hasil tersebut menandakan bahwa adanya hubungan yang kuat antara variabel $X$ (Gaya kepemimpinan) terhadap variabel Y (Kinerja karyawan).

Setelah mengetahui seberapa besar hubungan variabel $\mathrm{X}$ dan Y maka peneliti melakukan uji koefisien determinasi untuk mengetahui seberapa besar pengaruh antara variabel $\mathrm{X}$ terhadap variabel Y. Koefisien determinasi dapat diketahui besarnya pengaruh Gaya Kepemimpinan (X) Terhadap Kinerja Karyawan (Y) sebesar $61,16 \%$. Dan sisanya dipengaruhi oleh faktor lain.
Untuk mengetahui apakah hipotesis diterima atau ditolak maka dilakukan metode signifikansi korelasi metode uji t. Uji hipotesis untuk mengetahui ditolak atau tidak hipotesis dapat dinyatakan dengan kriteria sebagai berikut:

1. Jika $\mathrm{t}_{\text {hitung }}<\mathrm{t}_{\text {tabel }} \mathrm{H}_{0}$ ditolak $; \mathrm{H}_{\mathrm{a}}$ diterima (signifikan)

Jika $t_{\text {hitung }}<\mathrm{t}_{\text {tabel }}(8,693>2,011)$ maka Ho diterima, dan $\mathrm{H}_{\mathrm{a}}$ ditolak, artinya tidak terdapat pengaruh antara variabel gaya kepemimpinan kinerja karyawan pada PT Sarimelati Kencana Pizza Hut Delivery Cabang Ciputat.

2. Jika $\mathrm{t}_{\text {hitung }}>\mathrm{t}$ table $\mathrm{H}_{0}$ diterima $; \mathrm{H}_{\mathrm{a}}$ ditolak (tidak signifikan)

Jika $t_{\text {hitung }}>\mathrm{t}_{\text {table }}(8,693>2,011)$ maka Ho ditolak, dan $\mathrm{H}_{\mathrm{a}}$ diterima, artinya terdapat pengaruh antara gaya kepemimpinan terhadap variabel gaya kepemimpinan terhadap kinerja karyawan pada PT Sarimelati Kencana Pizza Hut Delivery Cabang Ciputat.

Dari hasil t hitung sebesar 8,693 maka dapat diketahui bahwa $\mathrm{t}$ hitung sebesar 8,693 > $\mathrm{t}$ table 2,011 maka Ho ditolak, dan $\mathrm{H}_{\mathrm{a}}$ diterima, artinya terdapat pengaruh antara variabel gaya kepemimpinan terhadap variabel kinerja karyawan.

\section{KESIMPULAN}

Variabel gaya kepemimpinan pada PT Sarimelati Kencana Pizza Hut Delivery Ciputat, dari 50 responden dengan 10 pernyataan, memberikan jawaban yang beragam. Untuk nilai liberal dan kharismatik adalah indikator tertinggi diperoleh dengan skor sebesar 4,28. Secara keseluruhan tanggapan responden atas pernyataan pada variabel gaya kepemimpinan diperoleh rata-rata skor sebesar 4,12 termasuk pada rentang skala 3,40-4,19 dengan kriteria baik. Responden yang memberikan penilaian sangat setuju dan setuju sebesar 90\% dan responden yang menjawab kurang setuju, tidak setuju dan sangat tidak setuju sebesar $10 \%$.

Variabel kinerja karyawan, responden memberikan jawaban yang beragam. Untuk nilai disiplin adalah indikator tertinggi diperoleh dengan skor sebesar 4,34. Secara keseluruhan tanggapan responden atas pernyataan pada variabel kinerja karyawan diperoleh rata-rata skor sebesar 4,23 termasuk pada rentang skala 4,20-5,00 dengan kriteria sangat baik. Responden yang memberikan penilaian sangat 
setuju dan setuju sebesar $87,60 \%$ dan responden yang menjawab kurang setuju, tidak setuju dan sangat tidak setuju sebesar $12,40 \%$.

Berdasarkan hasil analisis yang penulis lakukan, pengaruh gaya kepemimpinan terhadap kinerja karyawan yang mempunyai pengaruh yang kuat dan positif dalam meningkatkan kinerja karyawan. Berdasarkan hasil pengolahan data yang bersifat kuantitatif dengan menggunakan analisis statistik diperoleh koefisien korelasi (r) yaitu sebesar $=0.7821$. Sedangkan kontribusi variabel $\mathrm{x}$ dan variabel y koefisien determinasi sebesar $=61,16 \%$ yang menunjukan adanya kontribusi yang kuat antara variabel $\mathrm{X}$ dan $\mathrm{Y}$. sedangkan sisanya sebesar $=38,84 \%$ ditentukan oleh faktor lain yang belum diteliti dan berdasarkan hasil uji Hipotesis didapat, nilai $t_{\text {hitung }}>t_{\text {tabel }}(8,693>2,011)$ maka $H_{o}$ ditolak dan $\mathrm{H}_{\mathrm{a}}$ diterima.

\section{UCAPAN TERIMA KASIH}

Terima kasih kepada semua pihak yang telah membantu penelitian ini untuk PT Sarimelati Kencana Pizza Hut Delivery Cabang Ciputat, Universitas Pamulang dan para pihakpihak lainnya. semoga bermanfaat dan bisa meneliti lebih baik lagi dikemudian hari.

\section{DAFTAR ACUAN/PUSTAKA}

\section{Buku}

[1] Abdullah, M. 2014. "Manajemen dan Evaluasi Kinerja Karyawan”. Yogyakarta : Penerbit Aswaja Pressindo.

[2] Andi, Supangat. 2011. "Analisis Koefisien Determinasi”. Jakarta: Kencana

Prenada Media Group.

[3] Arikunto, Suharsimi. 2013. Prosedur Penelitian: Suatu Pendekatan Praktik. Jakarta: Rineka Cipta.

[4] Cushway, Barry. 2009. "Human Resource Management". Jakarta: PT Elex Media Kampitundo.

[5] Flippo B Edwin, "Prinsip-Prinsip Sumber Daya Manusia”, Edisi ke DuaBelas, Erlangga, Jakarta, 2011.

[6] Handoko, T. Hani. 2016. "Manajemen Personalia \& Sumber Daya Manusia”. Yogyakarta: BPFE Yogyakarta.

[7] Hasibuan, Malayu S.P. 2010. "Gaya kepemimpinan”. Bumi Aksara, Jakarta.

[8] Hasibuan, Malayu S.P. . 2011. "Manajemen Sumber Daya Manusia”. Bumi Aksara, Jakarta.
[9] Hasibuan, Malayu S.P. 2012. "Manajemen Sumber Daya Manusia”. Jakarta: PT Bumi Aksara.

[10] Hasibuan, Malayu S.P. 2013. "Manajemen Sumber Daya Manusia”. Cetakan Ketujuh Belas. Jakarta: PT Bumi Aksara.

[11] Hasibuan, Malayu S.P.. 2014. "Manajemen Sumber Daya Manusia”. Jakarta: PT Bumi Aksara.

[12] Heidjrachman dan Husnan, Suat. 2015. "Manajemen Personalia". BEFE. Yogyakarta. Yogyakarta.

[13] Hersey, Paul dan Kenneth, H. Blanchard. Diterjemahkan Manguprawira, S. 2015. "Kinerja Karyawan". Bandung: Alfabeta.

[14] Kartono, Kartini. 2010. "Pemimpin dan Kepemimpinan”. Edisi Pertama. Jakarta: Raja Grafindo Persada.

[15] Mangkunegara, AA., Anwar Prabu. 2014. "Manajemen Sumber Daya Manusia Perusahaan”, PT. Remaja Rosdakarya, Bandung.

[16] Robbins, S. \& Judge, T, 'Organizational Behavior", Edisi ke DuaBelas, Prentice Hall, 2012.

[17] Sedarmayanti. 2013. "Sumber Daya Manusia dan Produktivitas Kerja”. CV. Mandar Maju, Bandung.

[18] Simanjuntantak, Augustinus. 2013. Jurnal Manajemen Bisnis: "Pengelolaan Dan Pengembangan Sumber Daya Manusia Pada PT Aneka Sejahtera Engineering”, Universitas Kristen Petra, Vol. 1 No. 2.

[19] Sinambela, Lijan Poltak. 2016. "Manajemen Sumber Daya Manusia”. Jakarta: PT Bumi Aksara.

[20] Soekarso, Sosro Agus, Putong Iskandar, Hidayat Cecep. 2010. "Teori Gaya Kepemimpinan", Mitra Wacana Media, Jakarta.

[21] Sugiyono. 2013. Metode Penelitian Bisnis. Bandung: Alfabeta.

[22] Sugiyono. 2015. "Metode Penelitian Kombinasi (Mix Methods"). Bandung: Alfabeta.

[23] Sugiyono. 2016. "Metode Penelitian Kuantitatif, Kualitatif, dan $R \& D ”$ Bandung: Alfabeta.

[24] Sutikno, Sobry M. 2014. "Pemimpin dan Gaya Kepemimpinan”, Edisi Pertama Lombok: Holistica.

[25] Sutrisno, Edy. 2010. "Sumber Daya Manusia”. PT Gramedia, Surabaya, 2012.

[26] Thoha, Miftah. 2013. "Kepemimpinan dalam Manajemen”. Jakarta: Raja Grafindo Persada.

[27] Veithzal, Rivai. 2014. “Manajemen Sumber Daya Manusia Untuk Perusahaan”. Edisi ke 6, PT. Raja Grafindo Persada, Depok, 16956. 


\section{Teks/Jurnal}

[28] Ananda Pambudi, Skripsi, "Pengaruh Motivasi, Disiplin Kerja, Komitmen Organisasi dan Kompensasi Terhadap Kinerja karyawan pada PT. Mahkota Industries", Universitas Negeri Surakarta, 2014.

[29] Bambang Sulistyo, Skripsi, "Pengaruh Motivasi, Disiplin Kerja dan Komitmen Organisasi Terhadap Kinerja Karyawan Pada PT. Pan Brothers Tangerang", Universitas Mercubuana, Jakarta, 2014.

[30] Baskoro, Skripsi, "Pengaruh Motivasi Kerja, Kepuasan Kerja dan Komitmen Organisasi Terhadap Kinerja Karyawan PT. Panama Gatra", Universitas Diponegoro, Semarang, 2014.

[31] Farida, S. I. (2020, Juni 5). rakyatmerdekanews.com. Diambil kembali dari rakyatmerdekanews.com:

https://rakyatmerdekanews.com/2020/06/05/ca ra-bertahan-hidup-di-masa-pandemi-covid-19/

[32] Farida, S. I., Iqbal, M., \& Kurniasih, A. (2016). Pengaruh Kepercayaan Dan Komitmen Organisasi Terhadap Motivasi Kerja Serta Implikasinya Pada Kepuasan Kerja. Jurnal Kependidikan: Penelitian Inovasi Pembelajaran, 46(1), 121-134.

[33] Farida, S. I. (2018). Anggaran responsif gender sebagai suatu instrumen negara untuk pemenuhan hak perempuan di Indonesia. JIMF (Jurnal Ilmiah Manajemen Forkamma), 1(2).

[34] Farida, S. I., Prasetiyani, D., Safiih, A. R., Prasada, D., \& Ismanto, B. (2020). Pelatihan SDM: Usaha Konvensional menjadi Usaha Digital. Jurnal Abdi Masyarakat Humanis, l(2).

[35] Farida, S. I., \& Anjani, S. R. (2019). Menumbuhkan Jiwa Kepemimpinan Pada Mahasiswa di Lingkungan Universitas Pamulang. INOVASI, 6(2), 19-20.

[36] Farida, S. I., \& Khair, O. I. (2019). Leadership sebagai Dasar Kecerdasan Intelektual Mahasiswa Program Studi Manajemen di Universitas Pamulang. JIMF (Jurnal Ilmiah Manajemen Forkamma), 3(1).

[37] Prabasari, I Gusti Agung Ayu Maya dan I Gusti Salit Ketut Netra, Skripsi "Pengaruh Motivasi, Disiplin Kerja dan Komunikasi Terhadap Kinerja Karyawan Pada PT PLN (Persero) Distribusi Bali”, 2013.

[38] Siswandi, Skripsi, "Pengaruh Kepemimpinan, Komunikasi Internal dan Motivasi Kerja Terhadap Kinerja Karyawan Pand's Collection Semarang”, 2014.

[39] Tari Wulandari, Skripsi, "Pengaruh Motivasi Kerja, Disiplin Kerja, Budaya Kerja dan Komitmen Organisasi Terhadap Kinerja Karyawan Pada PT. Solusindo Pratama", Universitas Diponegoro Semarang, 2014. 